\title{
Magnetic Parkia pendula seed gum as matrix for Concanavalin A lectin immobilization and its application in affinity purification
}

\author{
MOACYR J.B.M. RÊGO ${ }^{1}$, SINARA M. ALMEIDA ${ }^{1,2}$, SÉRGIO A. BEZERRA ${ }^{1}$, \\ LUIZ B. CARVALHO JÚNIOR ${ }^{1}$ and EDUARDO I.C. BELTRÃ ${ }^{1}$ \\ ${ }^{1}$ Laboratório de Imunopatologia Keizo Asami/LIKA, Universidade Federal de Pernambuco/UFPE, \\ Av. Prof. Moraes Rêgo, s/n, CDU, 50670-901 Recife, PE, Brasil \\ ${ }^{2}$ Faculdade de Ciências, Educação e Tecnologia de Garanhuns/FACETEG, Universidade de Pernambuco/UPE, \\ Rua Capitão Pedro Rodrigues, 105, São José, 55290-000 Garanhuns, PE, Brasil
}

Manuscript received on August 2, 2013; accepted for publication on November 26, 2013

\begin{abstract}
The present work aimed to magnetize Parkia pendula seeds gum and use it as a matrix for Concanavalin A covalent immobilization. This composite was applied in affinity purification of glycoconjugates. Parkia pendula seeds were hydrated and the gum provenient from the supernatant was precipitated and washed with ethanol and dried. The gum was magnetized in co-precipitation using solutions of $\mathrm{Fe}^{+2}$ and $\mathrm{Fe}^{+3}$. Matrix activation was accomplished with $\mathrm{NaIO}_{4}$. Magnetized Parkia pendula seeds gum with covalently immobilized Concanavalin A was used as an affinity matrix for the recognition of bovine serum fetuin glycoprotein. Fetuin elution was carried out with a solution of glucose $(300 \mathrm{mM})$ and evaluated through SDS-PAGE. The efficiency of lectin immobilization and fetuin purification were $63 \%$ and $14 \%$, respectively. These results indicate that the composite produced is a promising magnetic polysaccharide matrix for lectins immobilization. Thus, such system can be applied for affinity purification allowing an easy recovery by magnetic field.
\end{abstract}

Key words: immobilization, magnetization, Parkia pendula seed gum, Concanavalin A.

\section{INTRODUCTION}

Many biomolecules have been isolated using separation techniques based on the interaction of biospecific molecules. Among these molecules of particular interest there is a class named lectins that are sugar-specific and cell-agglutinating proteins of non-immune origin (Sharon 2007). This class of proteins functions as recognition molecules in cell-molecule and cell-cell interactions in a variety

Correspondence to: Eduardo Isidoro Carneiro Beltrão

E-mail: ebeltrao@hotmail.com of biological systems (Ghazarian et al. 2010). Because of this, lectin-carbohydrate interactions are extensively studied, from basic to applied natural and clinical sciences. Such inter- and multidisciplinary approaches corroborate the importance of developing new methodologies for the study of lectin-saccharide interactions and their potential in biotechnology (Gemeiner et al. 2009).

Thus, immobilized lectins have found applications in the purification and analysis of polysaccharides (Fraguas et al. 2003), glycoconjugates 
(Yang et al. 2012) and cells (Ribeiro et al. 2012). For instance, the lectin extracted from Canavalia ensiformis, named Concanavalin A (Con A) has been extensively used in the isolation, fractioning and structural characterization of glycoproteins (Bucur et al. 2004, Uygun et al. 2012) and other important glycoconjugates bearing glucose and/or mannose residues (Fraguas et al. 2004).

Among the matrices used in protein immobilization, those which contain carbohydrates have become the focus of intense interest in biotechnology (Fraguas et al. 2003, 2004, Mislovicová et al. 2004, Angeli et al. 2009). Furthermore, to increase their performance, matrices have been magnetized to decrease the processing time of samples, the utilization of chemicals as well as to facilitate separation and process automation (Pan et al. 2005, Angeli et al. 2009).

In our laboratory, several kinds of supports have been magnetized with $\mathrm{Fe}_{3} \mathrm{O}_{4}$ magnetite particles prepared by co-precipitating $\mathrm{Fe}^{2+}$ and $\mathrm{Fe}^{3+}$. An example is a composite of the levan carbohydrate from Zimomonas mobilis that was easily ferromagnetized by Angeli et al. (2009) and subsequently recovered by a magnetic field. Glycoproteins recognized by lectins attached to the composite were recovered by washing the composite with a high ionic strength solution or with the lectin specific monosaccharide solution. Finally, these glycoproteins were collected from supernatant and the composite was reused. The washing procedures were facilitated by the magnetic field and all the process can be automated (Angeli et al. 2009).

Natural plant gums are another source of carbohydrates that can be exploited. Parkia pendula (Fabaceae) is a plant with pan tropical distribution found in the Atlantic Forest in the Northeast of Brazil and in the Brazilian Rainforest (Anderson and Pinto 1985). When hydrated with water, its seeds produce gum. In this way, the aim of this work was to magnetize the $P$. pendula seeds gum (PpeG) and use it as a matrix for Con A immobilization for affinity chromatography of glycoconjugates.

\section{MATERIALS AND METHODS}

\section{GUM PURIFICATION}

PpeG purification was carried out according to Rodrigues et al. (1993). Briefly, seeds of $P$. pendula were hydrated with distilled water for $24 \mathrm{~h}$ at $25^{\circ} \mathrm{C}$. The supernatant $(75 \mathrm{ml})$ was diluted in $300 \mathrm{ml}$ of distilled water, filtered through cheesecloth, and the gum was precipitated with $750 \mathrm{ml}$ of ethanol for $24 \mathrm{~h}$ at $4^{\circ} \mathrm{C}$. Afterwards, the precipitate was filtered through cheesecloth, washed twice with $150 \mathrm{ml}$ of ethanol at $4^{\circ} \mathrm{C}$, and dried at $36^{\circ} \mathrm{C}$ overnight.

\section{GuM MAGNETIZATION}

Dried PpeG (500 mg) was added to $50 \mathrm{~mL}$ of $1 \%$ acetic acid solution and stirred for $4 \mathrm{~h}$ at $25^{\circ} \mathrm{C}$. Solution ( $10 \mathrm{~mL}$ ) containing $1.1 \mathrm{M} \mathrm{FeCl}_{3} \cdot 6 \mathrm{H}_{2} \mathrm{O}$ and $0.6 \mathrm{M} \mathrm{FeCl}_{2} .4 \mathrm{H}_{2} \mathrm{O}(1: 1)$ was added to the mixture; the $\mathrm{pH}$ was adjusted to 11 with a $28 \%$ solution of $\mathrm{NH}_{4} \mathrm{OH}$ and heated in water-bath for $30 \mathrm{~min}$ at $80^{\circ} \mathrm{C}$. Finally, the magnetic particles were collected by centrifugation and washed with distilled water until the supernatant reached $\mathrm{pH}$ 7.0. PpeG magnetized (magPeG) was then dried at $25^{\circ} \mathrm{C}$, grounded and sieved (particle size $\leq 250 \mu \mathrm{m}$ ). From this time on the ${ }_{\text {mag }} \mathrm{PpeG}$ particles were collected by a magnetic field $(6,000 \mathrm{Oe})$. This procedure was performed according to Carneiro Leão et al. (1991), except for incubation time $(30 \mathrm{~min})$, temperature $\left(80^{\circ} \mathrm{C}\right)$ and final $\mathrm{pH}$ of the mixture (11). Particle sizes produced by this method were previously determined by Maciel et al. (2012), and in our work the same sieve was used in the final step.

\section{MATRIX ACTIVATION AND CON A IMMOBILIZATION}

One milliliter of sodium meta-periodate solution $(100 \mathrm{mg} / \mathrm{mL}$ in $0.01 \mathrm{M}$ sodium phosphate buffer $\mathrm{pH}$ 7.4 - from now on called buffer) was added to $50 \mathrm{mg}$ of ${ }_{\text {mag }}$ PpeG. Activation reaction was developed in the dark, under stirring for $4 \mathrm{~h}$ at $25^{\circ} \mathrm{C}$. The matrix was washed 10 times with buffer and incubated with $1 \mathrm{~mL}$ of a solution of Con A $(400 \mu \mathrm{g} / \mathrm{mL}$ in 
buffer) under stirring for $20 \mathrm{~h}$ at $4^{\circ} \mathrm{C}$. Afterwards, magPpeG-Con A was washed with buffer (5 times) and incubated with $1 \mathrm{~mL}$ of a solution of $0.03 \mathrm{M}$ sodium borohydride for $2 \mathrm{~h}$ at $4^{\circ} \mathrm{C}$. The matrix was washed 10 times with the buffer and kept at $4^{\circ} \mathrm{C}$ until use. Efficiency of Con A immobilization onto ${ }_{\mathrm{mag}} \mathrm{PpeG}$ was determined by the difference between the protein content of Con A offered and the one in the supernatant after immobilization process using Lowry et al. (1951). All experiments were carried out in quintuplicates.

AfFinity Binding WITH ${ }_{\text {MAG }}$ PPEG-CON A

One milliliter of a solution of fetuin $(400 \mu \mathrm{g} /$ $\mathrm{mL}$ in buffer) was incubated with ${ }_{\mathrm{mag}} \mathrm{PpeG}-\mathrm{Con} \mathrm{A}$ (50mg) for $1 \mathrm{~h}$ under stirring at $25^{\circ} \mathrm{C}$. Afterwards, the magnetic particles were collected and washed twice with the buffer. Protein determination was established for the supernatants according to Lowry et al. (1951). The washed magnetic particles were incubated with $0.3 \mathrm{M}$ glucose $(1 \mathrm{~mL})$ for $1 \mathrm{~h}$ at $25^{\circ} \mathrm{C}$ in order to disrupt the Con A-fetuin complex. Efficiency of fetuin recognition by Con A immobilized on the ${ }_{\text {magPeG }}$ was determined by the difference between the fetuin offered and the one in the supernatant. All experiments were carried out in quintuplicates.

SDS-PAGE

Samples were dialyzed, lyophilized and resuspended in distilled water prior to the gel running. SDS-PAGE (12.5\%) was carried out according to Laemmli (1970) and visualized with silver staining according to Keshoven and Dernick (1985). Protein standards used were bovine serum albumin $(66 \mathrm{kDa})$, fetuin (64 kDa) egg-albumin (46 kDa), gliceraldehyde-3-P enzyme (36 kDa), carbonic anhydrase $(29 \mathrm{kDa})$, trypsinogen (24 kDa) and Con A (32 kDa), obtained from Sigma-Aldrich (St. Louis, MO, USA).

PhySICAL-CHEMICAL PARTIAL CHARACTERIZATION

PpeG and ${ }_{\text {mag }}$ PpeG were analyzed for elemental content and infrared spectrometry in the Analytical Laboratory of the Chemistry Department at the
Federal University of Pernambuco (UFPE), Brazil. Fourier transform infrared (FTIR) spectrum from the $\mathrm{KBr}$ pellet method in the range of $4000-400 \mathrm{~cm}^{-1}$ was recorded in a BRUKER instrument model IFS 66. Elemental analysis of samples was determined by a LECO Elemental Analyzer CHNS O932 and Unicam 929 AA spectrophotometer (USA).

\section{RESULTS AND DISCUSSION}

PhySICO-ChEMICAL PARTIAL CHARACTERIZATION

The element's composition of the free and magnetized PpeG (Table I) showed the presence of carbon and hydrogen only. Nitrogen and sulfur detections were not observed in our preparation of PpeG. Furthermore, no amine and amide characteristic bands were visualized in the gum infrared analysis (Fig. 1). Anderson and Pinto (1985) evaluated the gum exudates from Parkia bicolor and P. biglobosa, and the gum extracted from the seed pods of $P$. pendula. According to their results all three gum polysaccharides were of high weightaverage molecular weight and intrinsic viscosities. The major features revealed that there are close similarity of the exudate gums from $P$. bicolor and P. biglobosa, and the extent of their differences from $P$. pendula seed-pod gum. These differences were observed both in ratios of found carbohydrates and in nitrogen values. The presence of 0.92 (P. bicolor) and $0.95 \%$ ( $P$. biglobosa $) \mathrm{N}$ content indicates the presence of $6 \%$ of protein. However, the $\mathrm{N}$ content of $P$. pendula was only $0.35 \%$ which indicates a lower $\mathrm{N}$ content and revels that the gum polysaccharide from the seed pods of $P$. pendula must be regarded as a typical plant gum (Anderson and Pinto 1995). The lack of $\mathrm{N}$ content in PpeG confirms the existence of differences among gums extracted from different species of this plant, besides variation between the same species collected in distinct places. Elemental analysis has also demonstrated a decrease of $\mathrm{C}$ and $\mathrm{H}$ content after the magnetization procedure. The magnetite incorporation in the PpeG explained the reduction observed. 
TABLE I

Element composition of free and magnetized $P$. pendula seed gum.

\begin{tabular}{ccccc}
\hline \multirow{2}{*}{ Sample } & \multicolumn{4}{c}{$\%$} \\
\cline { 2 - 5 } & Nitrogen & Carbon & Hydrogen & Sulfur \\
\hline $\begin{array}{c}\mathrm{PpeG}^{\mathrm{a}} \\
(0.500 \mathrm{mg} / \mathrm{mL})\end{array}$ & 0 & 35.83 & 5.29 & 0 \\
$\begin{array}{c}\mathrm{mag} \mathrm{PpG}^{\mathrm{a}} \\
(0.500 \mathrm{mg} / \mathrm{mL})\end{array}$ & 0 & 9.24 & 1.98 & 0 \\
\hline
\end{tabular}

${ }^{\mathrm{a}} \mathrm{PpeG}$ and ${ }_{\mathrm{mag}} \mathrm{PpeG}$ stands for free and magnetized $P$. pendula seed gum, respectively.

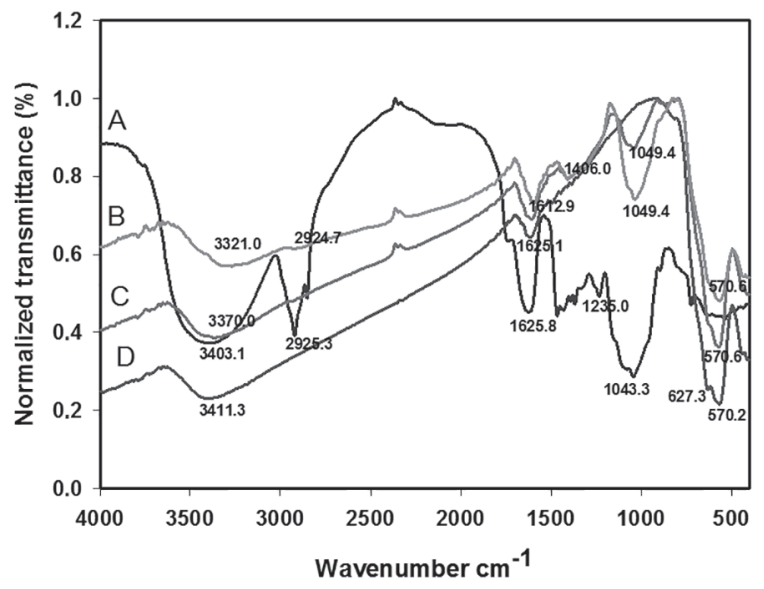

Fig. 1 - Infrared spectra of $P$. pendula gum (A), magnetized gum using $0.500 \mathrm{mg} / \mathrm{mL}(\mathrm{B})$ and $0.100 \mathrm{mg} / \mathrm{mL}$ (C) of the gum and magnetite (D).

Figure 1 presents the infrared spectra of the free PpeG (A), magnetic PpeG at different concentrations $0.500 \mathrm{mg} / \mathrm{mL}(B)$ and $0.100 \mathrm{mg} /$ $\mathrm{mL}(\mathrm{C})$ and magnetite (D). Infrared spectroscopy showed that $\mathrm{O}-\mathrm{H}$ groups are present in the PpeG polysaccharide, magnetite and magnetic $\mathrm{PpeG}$ near wavenumber of $3400 \mathrm{~cm}^{-1}$ with higher intensity for PpeG (3411.3). These $\mathrm{O}-\mathrm{H}$ groups correspond to those present in organic compounds. The magnetic PpeG presented absorption bands in $2924.7 \mathrm{~cm}^{-1}$ due to stretching vibration of $\mathrm{C}-\mathrm{H}$ bond band in $1049.4 \mathrm{~cm}^{-1}$ and due to stretching vibration of $\mathrm{C}-\mathrm{OH}$ bond. These bonds are also present in the PpeG polysaccharide with bands in $2925.3 \mathrm{~cm}^{-1}$ (stretching vibration of $\mathrm{C}-\mathrm{H}$ bond), band in 1043.3 $\mathrm{cm}^{-1}$ (stretching vibration of $\mathrm{C}-\mathrm{OH}$ ) indicative of the presence of polysaccharide in the magnetic particles. Previous studies (Waldron 1955, Pan et al. 2005) reported that the characteristic absorption bands of the $\mathrm{Fe}-\mathrm{O}$ bond of bulk magnetite were around $570 \mathrm{~cm}^{-1}$. However, Ma et al. (2003) observed that these two bands shift of about 600 and $440 \mathrm{~cm}^{-1}$ respectively, and the band near $600 \mathrm{~cm}^{-1}$ is split into two peaks of 631.4 and $582.9 \mathrm{~cm}^{-1}$. Here, a band near $600 \mathrm{~cm}^{-1}$ is also shown split in two peaks of 627.3 and $570.2 \mathrm{~cm}^{-1}$ for magnetite. Magnetic PpeG particles presented a similar band at $570.6 \mathrm{~cm}^{-1}$ with a lower peak at 627.3. This difference was also observed by Maciel et al. (2012) for magnetic levan. According to the authors, a difference in these bands can indicate that interactions between polysaccharide and magnetite had inter-molecular origins. The results confirm the success of the magnetization process of PpeG.

PpeG infrared spectrum is typical for polysaccharide (Fig. 1 A) as those reported for cellulose (Corti et al. 2004) and the cashew gum (Silva et al. 2004). The $\mathrm{C}=\mathrm{O}$ axial deformation at the wavenumber $1736 \mathrm{~cm}^{-1}$ typical of glucuronic acid is present for the PpeG. Corti et al. (2004) observed that 1656, 1631 and $1558 \mathrm{~cm}^{-1}$ infrared bands corresponded to axial deformation of carbonyl in amide (in our case related to carbonyl of peptide bonds), N-H angular deformation of amine and $\mathrm{N}-\mathrm{H}$ angular deformation of amide, respectively. Similar bands were observed by Pan et al. (2005). The absence of these bands in the spectrum of PpeG and the elemental analysis confirmed that no proteins were found in this structure.

\section{IMMOBILIZATION AND ACTIVITY OF CON A}

The partial oxidation of the gum by $\mathrm{NaIO}_{4}$ aimed to randomly introduce aldehydes groups in the vicinal hydroxyls of the carbohydrates (MartinezBarragan and Angel 2001, Hong et al. 2004). These aldehydes groups then react to amine group from amino acids chains such as lysine, sulfhydryl group from cysteine and imidazole group from histidine (Fraguas et al. 2004). 
The immobilization of Con A on the PpeG retained about $62 \%$ of the offered protein (Table II). Kobayashi and Ichishima (1991) reported 40\% of retention immobilizing bovine serum albumin on cellulose. Cavalcante et al. (2006) immobilized trypsin onto a membrane of a cellulosic exopolysaccharide produced by Zoogloea $s p$. in sugarcane molasses. Carbonyl groups were introduced into the matrix by sodium meta-periodate oxidation and the enzyme was immobilized either directly or through bovine serum albumin (BSA) as a spacer. The trypsin-membrane and trypsin-BSAmembrane retained $37.2 \%$ and $9.16 \%$, respectively. It is worthwhile to notice that not all carbohydrate moieties are oxidized by the $\mathrm{NaIO}_{4}$ (Silva et al. 2004). Furthermore, the PpeG structure is not completely identified yet and its linear and branched chains are not established.

TABLE II

Immobilization efficiency of Con A on

${ }_{\text {ag }}$ PeG and efficiency of fetuin recognition

by the immobilized Con $A$ on ${ }_{\text {mag }}$ PpeG.

\begin{tabular}{ccc}
\hline & $\begin{array}{c}\text { Con A } \\
\text { immobilization }\end{array}$ & $\begin{array}{c}\text { Fetuin } \\
\text { recognition }\end{array}$ \\
\hline Offered $(\mu \mathrm{g} / \mathrm{mL})$ & 400 & 400 \\
Supernatant $^{\mathrm{a}}(\mu \mathrm{g} / \mathrm{mL})$ & $147 \pm 9.6$ & $343.8 \pm 11.23$ \\
Retained $^{\mathrm{a}}(\mu \mathrm{g})$ & $253 \pm 9.7$ & $56.2 \pm 11.23$ \\
Efficiency $^{\mathrm{a}}(\%)$ & $62.6 \pm 2.30$ & $13.8 \pm 2.95$ \\
\hline
\end{tabular}

${ }^{a}$ All experiments were carried out in quintuplicates and the results expressed as mean \pm Standard deviation.

The fetuin, composed of one polypeptide chain (Spiro 1963) containing 3 oligosaccharides N-linked (Spiro and Bhoyroo 1974) and 3 O-linked (Green et al. 1988), was used as a model. Table II summarizes the results of this purification and shows that about $14 \%$ of fetuin was complexed to about $63 \%$ of Con A. This relationship accounts for about 01 mole of fetuin per 08 mole of Con A considering that the molecular weights are respectively $64 \mathrm{kDa}$ (Johnson and Heath 1986a) and $32 \mathrm{kDa}$ (Fontaniella et al. 2004). The ratio of 1:1 mole: mole of fetuin and Con A was probably not accomplished due to steric hindrance caused by the immobilization procedure.

Besides that, even with the higher quantity of oligosaccharides present in fetuin and its recognition by soluble Con A, Johnson and Heath (1986b), Green et al. (1988) observed that among the $23 \mathrm{~N}$-types of oligosaccharides that could be found in fetuin (di- or tri-branched), only the di-branched ones would be recognized, which corresponds to $17 \%$.

Figure 2 shows three bands (64, 58 e 55 $\mathrm{kDa}$ ) for the fetuin (Lane B) in the SDS-PAGE. Nevertheless, only two bands (64 e $58 \mathrm{kDa}$ ) appear for the purified fetuin (Lane C) by affinity binding

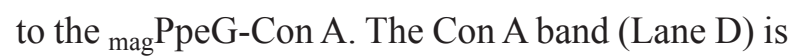
not present in the Lane $\mathrm{C}$, which demonstrates that this lectin was covalently linked to the ${ }_{\mathrm{mag}} \mathrm{PpeG}$, and was not detached during the washings.

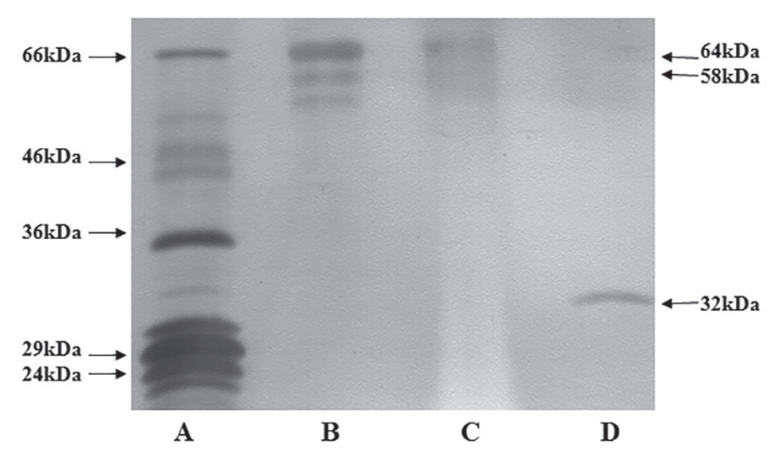

Fig. 2 - SDS-PAGE of eluted fetuin from the immobilized

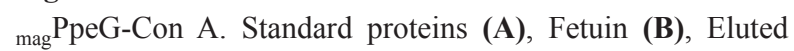
Fetuin (C), Con A (D).

Johnson and Heath (1986a) observed that native fetuin, pre-fetuin and glycosilated fetuin (found in the rough endoplasmatic reticulum) presented molecular weight of 64,49 and 58 $\mathrm{kDa}$, respectively, in SDS-PAGE. Therefore, the observed 58kDa band in Figure 2 would be a fetuin with two N-type glycosylation.

According to Green et al. (1988) the recognition of Con A for di-branched fetuin justifies the absence of the $55 \mathrm{kDa}$ band in the lane $\mathrm{C}$ of the SDS-PAGE (Fig. 2). Authors observed that L-PHA 
(Leukoagglutinating Phytohemagglutinin) and RCA-I (Ricinus Communis Agglutinin) interact with carbohydrates depending on the type of the bound between the saccharide residue and its position in the oligosaccharide chain. L-PHA has strong interaction if the neuraminic acid, present in fetuin, has one terminal $\alpha-2,3$ bound, linked to the mannose's branching $\alpha-1-6$. Otherwise, if the bound is $\alpha-2,6$ on the same branching ( $\alpha-1-6)$ the recognition of the sugar by L-PHA cannot be made. Furthermore, no significant interference, in recognition, was observed if the sugar was located on another branching (Green et al. 1988). So, the spatial changes caused by certain saccharides bearing N-type glycosylation in fetuin, would, possibly, impose a more or less stable interaction between Con A and fetuin.

Results from our groups have already demonstrated the use of other magnetized polysaccharides such as levan as affinity matrix for direct lectin purification (Angeli et al. 2009) or as matrix for trypsin immobilization (Maciel et al. 2012) and cellulosic exopolysaccharide produced by Zoogloea sp. as a film support for trypsin immobilization (Cavalcante et al. 2006). Here, we demonstrated that Ppeg was efficiently magnetized and used as matrix for Con A immobilization. ${ }_{m a g}$ PpeGCon A was used as an affinity chromatography matrix for purification of fetuin under a magnetic field indicating that it is a promising matrix for biotechnology application.

\section{ACKNOWLEDGMENTS}

The Conselho Nacional de Desenvolvimento Científico e Tecnológico (CNPq) supported this work The authors have declared no conflict of interest.

\section{RESUMO}

O presente trabalho objetivou magnetizar a goma de sementes de Parkia pendula e demonstrar seu uso como matriz para imobilização covalente da lectina Concanavalina A. O composto foi aplicado em puri- ficação de glicoconjugados por afinidade. Sementes de Parkia pendula foram hidratadas e a goma do sobrenadante foi precipitada, lavada com etanol e seca. A goma foi magnetizada pelo método de coprecipitação usando soluções de $\mathrm{Fe}^{+2} \mathrm{e} \mathrm{Fe}$. A ativação da matriz foi realizada com $\mathrm{NaIO}_{4}$. Goma das sementes de Parkia pendula magnetizada com Concanavalina A imobilizada covalentemente foi usada como matriz de afinidade para o reconhecimento da glicoproteína fetuína sérica bovina. Eluição de fetuína foi realizada com uma solução de glicose $(300 \mathrm{mM})$ e avaliada por meio de SDS-PAGE. A eficiência de imobilização da lectina e purificação de fetuína foram $63 \%$ e $14 \%$, respectivamente. Esses resultados indicam que o composto produzido é uma matriz polissacarídica magnética promissora para imobilização de lectinas. Esse sistema pode ser aplicado para purificação por afinidade que permite fácil recuperação por campo magnético.

Palavras-chave: imobilização, magnetização, goma da semente de Parkia pendula, Concanavalina A.

\section{REFERENCES}

ANDERSON DMW AND PINTO GL. 1985. Gum polysaccharides from three Parkia species. Phytochem 24: 77-79.

ANGELI R ET AL. 2009. Ferromagnetic Levan Composite: An Affinity Matrix to Purify Lectin. J Biomed Biotechnol Article ID 179106: 1-6.

BuCUR B, DANET AF AND MARTY JM. 2004. Versatile method of cholinesterase immobilisation via affinity bonds using Concanavalin A applied to the construction of a screen-printed biosensor. Biosens Bioelectron 20: 217-225.

CARNEIRO-LẼ̃o AMA, OLIVEIRA EA AND CARVALHo JR LB. 1991. Immobilization of protein on ferromagnetic Dacron. Appl Biochem Biotechnol 31: 53-58.

CaVAlcante AHM, CARVAlHo JR LB AND CARneiroDA-CUNHA MG. 2006. Cellulosic exopolysaccharide produced by Zoogloea sp. as a film support for trypsin immobilisation. Biochem Eng J 29: 258-261.

Côelho Ral, Jaques Ga, Barbosa AD, Velazquez G, Montenegro SML, AZEVEdo WM AND CARVALHO JR LB. 2002. Magnetic polysiloxane-polyvinyl alcohol composite as solid-phase in chemiluminescent assays. Biotechnol Lett 24: 1705-1708.

CORTI GS, BotARO VR, GIL LF AND GIL RPF. 2004. Estudo da Capacidade de Complexação de Ílons $\mathrm{Cu}^{2+}$ em Solução Aquosa Usando Celulose Modificada com Anidrido Succínico e com Poliaminas. Polim Cienc Tecnol 14: 313-317. 
Fontaniella B, Millanes AM, Vicente C and Legaz ME. 2004. Concanavalin A binds to a mannose-containing ligand in the cell wall of some lichen phycobionts. Plant Physiol Biochem 42: 773-779.

Fraguas LF, Batista-Vieira F AND CARLSSON J. 2004. Preparation of high-density Concanavalin A adsorbent and its use for rapid, high-yield purification of peroxidase from horseradish roots. Chromatogr B Biomed Sci Appl 803: 237-241

Fraguas lF, Plá A, Ferreira F, Massaldi H, SuÁrez N AND BATISTA-VIEIRA F. 2003. Preparative purification of soybean agglutinin by affinity chromatography and its immobilization for polysaccharide isolation. Chromatogr B Biomed Sci Appl 790: 365-372.

Gemeiner P, MisloviČOVÁ D, TKÁČ J, ŠVITEL J, PÄTOPRSTÝ V, Hrabárová E, Kogan G and KožÁr T. 2009. Lectinomics II. A highway to biomedical/clinical diagnostics. Biotechnol Adv 27: 1-15.

GHAZARIAN H, IDONI B AND OPPENHEIMER SB. 2010. A glycobiology review: Carbohydrates, lectins and implications in cancer therapeutics. Acta Histochem 113: 236-247.

Green ED, Aldelt G And BAEnZIGer JU. 1988. The asparagine-linked oligosaccharides on bovine fetuin. Structural analysis of $\mathrm{N}$-glycanase-released oligosaccharides by 500-Megahertz ${ }^{1}$ H-NMR spectroscopy. J Biol Chem 263: 18253-18268.

Hong X, GuO W, Yuan H, Li J, LiU Y, Ma L, BAi Y AND Li T. 2004. Periodate oxidation of nanoscaled magnetic dextran composites. J Magn Magn Mater 269: 95-100.

JOHNSON WV AND HEATH E. 1986a. Structural features of bovine fetuin revealed from analysis of the primary translation product: anomalous behavior on sodium dodecyl sulfate-polyacrylamide gel electrophoresis is due largely to peptide and not solely to carbohydrate. Arch Biochem Biophys 251: 732-737.

JOHNSON WV AND HEATH E. 1986b. Evidence for Posttranslational 0-glycosylation of fetuin. Biochemistry 25: 5518-5525.

Keshoven HJ AND DeRnick R. 1985. Simplified method for silver staining of proteins in polyacrylamide gels and the mechanism of silver staining. Electrophoresis 6: 103-112.

KoBAYASHI M AND ICHISHIMA E. 1991. Application of periodate oxidized glucans to biochemical reactions. J Carbohydr Chem 10: 635-644.

LAEMMLI UK. 1970. Cleavage of structural proteins during the assembly of the head of bacteriophage T4. Nature 227: 680-685.

LOWRY OH, ROSEBROUGH NJ, FARR AL AND RANDALL RJ. 1951. Protein measurement with the folin phenol reagent. J Biol Chem 193: 265-275.

Ma M, Zhang Y, Yu W, Shen H, Zhang H AND Gu N. 2003. Preparation and characterization of magnetite nanoparticles coated by amino silane. Colloids Surf A 212: 219-226.

Maciel JC, ANDrad PL, Neri DFM, Carvalho JR LB, Cardoso CA, Calazans GMT, Albino Aguiar J AND SILVA MPC. 2012. Preparation and characterization of magnetic levan particles as matrix for trypsin immobilization. J Magn Magn Mater 324: 1213-1216.

MARTINEZ-BARRAGAN JJ AND ANGEL RM. 2001. Identification of a Putative Coreceptor on Vero Cells That Participates in Dengue 4 Virus Infection. J Virol 75: 7818-7827.

Mislovicová D, Masarová J, Vikartovská A, Gemeiner P AND MichalKovÁ E. 2004. Biospecific immobilization of mannan-penicillin $G$ acylase neoglycoenzyme on Concanavalin A-bead cellulose. J Biotechnol 110: 11-19.

NERI DFM, BALCÃo VM, CARDOSO SM, SILVA AMS, DOMINGUES MRM, TORRES DPM, RODRIGUES LRM, CARVAlHo JR LB AND TeIXEIRA JAC. 2011. Characterization of galactooligosaccharides produced by b-galactosidase immobilized onto magnetized Dacron. Int Dairy J 21: 172-178.

PAN BF, GAO F AND GU HC. 2005. Dendrimer modified magnetite nanoparticles for protein immobilization. J Colloid Interface Sci 284: 1-6.

Ribeiro A, CATARINo S AND FERreira RB. 2012. Multiple lectin detection by cell membrane affinity binding. Carbohydr Res 352: 206-210.

Rodrigues JF, PAULA RCM AND CosTA SMO. 1993. Métodos de isolamento de gomas naturais e comparação através de goma de cajueiro. Polim Cienc Tecnol 1:31-36.

SHARON N. 2007. Lectins: Carbohydrate-specific Reagents and Biological Recognition Molecules. J Biol Chem 282(5): 2753-2764.

Silva DC, PAUla RCM, FeITOSA JPA, BRITO ACF, MACIEL JS AND PAULA HCB. 2004. Carboxymethylation of cashew tree exudate polysaccharide. Carbohydr Polym 58: 163-171.

SORIA F, Ellenrieder G, OliveIRA GB, CABrera M AND CARVALHO JR LB. 2012. $\alpha$-L-Rhamnosidase of Aspergillus terreus immobilized on ferromagnetic supports. Appl Microbiol Biotechnol 93: 1127-1134.

SPIRO RG. 1963. Demonstration of a single peptide chain in the glycoprotein fetuin: terminal amino acid analyses and studies of the oxidized and reduced alkylated preparations. J Biol Chem 238: 644-649.

SPIRO RS AND BHOYROO V. 1974. Structure of the O-glycosidically linked carbohydrate units of fetuin. J Biol Chem 249: 5704-5717.

UYGUN M, UYGUN DA, ÖZÇALIŞKAN E, AKGÖL S AND DENIZLI AJ. 2012. Concanavalin A immobilized poly(ethylene glycol dimethacrylate) based affinity cryogel matrix and usability of invertase immobilization. Chromatogr B Biomed Sci Appl 887-888: 73-78.

YANG G, CUI T, CHEN Q, MA T AND Li Z. 2012. Isolation and identification of native membrane glycoproteins from living cell by concanavalin A-magnetic particle conjugates Anal Biochem 421: 339-341.

WALDRON RD. 1955. Infrared spectra of ferrites. Phys Rev 99: 1727. 
